УДК 32.019.5:355.01] (470+477-6512)"2014/2020"

DOI https://doi.org/10.31470/2518-7600-2021-11-135-159

\author{
MEDIA SPACE IN THE NON-CONTROLLED \\ UKRAINIAN TERRITORIES OF LUHANSK AND \\ DONETSK REGIONS IN 2014-2020 IN THE CONDITIONS \\ OF THE RUSSIAN-UKRAINIAN WAR
}

\title{
МЕДІАПРОСТІР НА НЕПІДКОНТРОЛЬНИХ УКРАЇНІ ТЕРИТОРІЯХ ЛУГАНСЬКОЇ ТА ДОНЕЦЬКОЇ ОБЛАСТЕЙ У 2014- 2020 РР. В УМОВАХ РОСІЙСЬКО- УКРАЇНСЬКОЇ ВІЙНИ
}

\section{МЕДИАПРОСТРАНСТВО НА НЕПОДКОНТРОЛЬНОЙ УКРАИНЕ ТЕРРИТОРИИ ЛУГАНСКОЙ И ДОНЕЦКОЙ ОБЛАСТИ В 2014- 2020 ГГ. В УСЛОВИЯХ РОССИЙСКО-УКРАИНСКОЙ ВОЙНЫ}

Віталій Коцур,

доктор історичних наук,

дочент, декан факультет

гуманітарно-природничої

освіти і соціальних

технологіü, kotsurv@ukr.net https://orcid.org/0000-00016647-7678ДВНЗ

«Переяслав-Хмельнищький державний педагогічний університет імені Григорія Сковороди», вул. Сухомлинського, 30, м. Переяслав Київська обл., Україна, 08401
Vitalii Kotsur,

Doctor of Historical Sciences, PhD in Political Sciences, Assistant Professor, Dean of Faculty of Humanitarian and Natural Education and Social Technologies,kotsurv@ukr.net https://orcid.org/0000-00016647-7678Pereiaslav-Khmelnyts kyi Hryhorii Skovoroda State Pedagogical University 08401, Ukraine, Kyiv region, Pereiaslav, Sukhomlynskyi Str., 30 


\section{Леся Коцур,}

кандидат історичних наук,

доиент кафедри політологіі

dombrovska_ne@ukr.net

https://orcid.org/0000-0001-

8996-1606 ДВНЗ

«Переяслав-Хмельницький

державний педагогічний

університет імені Григорія

Сковороди»,

вул. Сухомлинського, 30,

м. Переяслав Київська обл.,

Украӥна, 08401

\section{Ірина Іваннікова,}

магістрантка кафедри

nолітологї franko-a@ukr.net

ORCID: orcid.org/0000-0002-

8539-2642 ДВНЗ

«Переяслав-Хмельницький

державний педагогічний

університет імені Григорія

Сковороди»,

вул. Сухомлинського, 30,

м. Переяслав Київська обл.

\section{Lesia Kotsur,}

PhD in History, Senior Lecturer,

Assoc. Prof. ofDepartment of

Political Sciences

dombrovska_ne@ukr.net

https://orcid.org/0000-0001-

8996-1606

Pereiaslav-Khmelnytskyi

Hryhorii Skovoroda State

Pedagogical University08401,

Ukraine, Kyiv region,

Pereiaslav, Sukhomlynskyi Str.,

30

\section{Iryna Ivannikova,}

Master's student ofDepartment

of Political Sciences franko-

a@ukr.net ORCID:

orcid.org/0000-0002-8539-2642

Pereiaslav-Khmelnytskyi

Hryhorii Skovoroda State

Pedagogical University08401,

Ukraine, Kyiv region,

Pereiaslav, Sukhomlynskyi

Str., 30

Україна, 08401

\section{ABSTRACT}

Considering the current geopolitical situation in Ukraine and information and communication challenges from Russia, which is waging an occupation-hybrid war against our state, special attention should be paid to shaping the worldview of the population in Ukraine's non-controlled territories of Luhansk and Donetsk regions through the media in 2014-2020. An important role in shaping the Russian worldview of the population in the territories 
not under Ukraine's control is played by the media of the so-called ' $L P R$ ' and 'DPR', which operate through methods of total propaganda, intimidation and manipulation. The mass media of the unrecognized republics are effectively used by the Russian Federation as a tool to influence the information and economic space of the occupied territories.

In this review, the authors reveal the changes that took place in the digital media space and print media since 2014 in the territories non-controlled by Ukraine. The influence of the local media on the formation of the worldview of Luhansk and Donetsk regions'population is defined.

It is determined that over the past five years, practically all Ukrainian information channels have been supplanted in the noncontrolled by Ukraine territories of Luhansk and Donetsk regions. They were replaced by Russian or pro-Russian local mass media, the purpose of which was to promote the values and worldview of the narratives of 'russkiy mir' in these territories.

It has been proved that the population of Luhansk and Donetsk regions has actually found itself in an information vacuum, with each post, tweet or article being monitored by 'LDPR public authorities'. There are no Ukrainian newspapers and magazines in the press outlets, while Russian print media predominate.

It is determined that feelings of fear for the Ukrainian state policy are artificially formed among local inhabitants in noncontrolled territories.

The local press primarily publishes articles about 'spies' and 'agents' of the SBU, as well as nostalgia for the Soviet Union is formed, by glorifying the missing soldiers of the Great Patriotic War.

Keywords: Ukraine, Russian Federation, 'hybrid war', 'russkiy mir', non-controlled territories, mass media, press, print media, LDPR, LPR (Luhansk People's Republic), DPR (Donetsk People's Republic).

Постановка проблеми. Наприкінці XX - початку XXI століть засоби масової інформації стали не тільки інструментом 
комунікації, а й потужною зброєю, яка використовується державами для досягнення їхніх зовнішньополітичних цілей. Перебування незалежних країн під контролем іноземного інформаційного поля дозволяє окремим державам формувати суспільні настрої згідно їхніми інтересами та втручатися у внутрішню політику суверенних держав.

Оскільки після здобуття Україною незалежності у 1991 р. вона й надалі продовжила перебувати в російському інформаційному полі, то поступово на їі теренах сформувалися потенційні осередки сепаратизму, настрої яких постійно підживлювались спекуляціями на мовному підгрунті, так званих утисках російськомовних. Скориставшись наслідками революційних подій в Україні 2014 р. Російська Федерація (РФ) розгорнула проти України інформаційно-пропагандистську кампанію та під приводом захисту російськомовного населення анексувала український Крим й розгорнула збройну агресію в низці районів Луганської та Донецької областей. Після захоплення окремих територій бойовиками вони взяли під контроль усю медійну сферу, з метою подальшого насадження ідей «русского мира» та формування нової ідентичності громадян.

В умовах сьогодення, коли виникає проблема якісної реінтеграції в українське суспільство як людей з окупованих територій, так і тих, що не виїжджають звідти, актуально дослідити становище медіа на непідконтрольних Україні територіях так званих «ЛНР» та «ДНР», які за допомогою методів тотальної пропаганди, залякування та маніпулювання формують російський світогляд населення на непідконтрольних територіях.

Аналіз останніх досліджень публікацій. Запропонована проблематика ще не стала предметом комплексних досліджень, у зв'язку з обмеженим доступом інформаційних контактів України з окупованими територіями та неможливістю провести фахове дослідження незалежними соціологічними й науковими установами, які можуть стати об'єктами насильства з боку 
російських бойовиків. Попри ці складнощі, до вивчення цієї теми прикута увага центру Разумкова (Центр Разумкова..., 2020), Міністерства інформаційної політики України (Міністерство інформаційної..., 2020), Національного інституту стратегічних досліджень (Національній інститут.., 2020), аналітичного центру «Фабрика думки «Донбас» (який належить Громадській організації «Громадський холдинг «Група впливу»») (Громадська організація.., 2020), Міністерства 3 питань реінтеграції тимчасово окупованих територій (Міністерство з питань.., 2020) та Інституту масової інформації (Інститут масової інформації..., 2020), які періодично проводять окремі дослідження, які відбивають зміни у медіапросторі Луганської та Донецької областей. Також ця проблематика частково розкрита у монографії «Інформаційні чинники системи інтеграторів Донбасу і Криму в загальноукраїнській єдності» (Інформаційні чинники..., 2016). Водночас слід зауважити, що аналіз друкованих 3MI, які там $€$ не менш популярними ніж соціальні медіа, практично відсутній.

Метою огляду $\epsilon$ вивчення змін в цифровому медіапросторі та друкованих 3МІ на непідконтрольних Україні територіях та їх вплив на формування світогляду населення Луганської та Донецької областей.

Виклад основного матеріалу. В сучасному світі медіа відіграють ключову роль у формуванні світогляду населення. Одним із першочергових завдань бойовиків так званих республік «ЛНР» та «ДНР» було - встановлення контролю над інформаційною сферою 3 метою позбавлення місцевого населення до незалежних засобів масової інформації (ЗМI). Зокрема, з початком конфлікту на сході України у 2014 р. в Донецькій області було вщент розгромлено 28 офісів місцевих 3МI, що змусило частину місцевих журналістів виїхати в інші регіони України. На уламках цих офісів на окупованих територіях Луганської й Донецької областей було створено чотири місцеві телеканали. Зокрема, в «ДНР» з'явились такі 
мовники як: «Оплот ТВ», який було утворено на основі захопленого місцевого телеканалу «Перший муніципальний»; «Новороссия ТВ» Губарєва, що працює на захопленій частоті ЮНІОНу та «1+1»; «Первый республиканский»; «Второй республиканский», колишній ЮНІОН), а також працює російське телебачення (Голуб, 2019). Згодом з'явились й такі місцеві телеканали як: «Авеста», «Горловка-ТВ», «ТВ-Сфера», «Шахтарська студія телебачення», «Торезьке телебачення» («ЗМІ ДНР»..., 2020).

Телеканали на захоплених територіях Луганської області зазнали також змін. Зокрема, у так званій «ЛНР» одним із найпоширеніших каналів є «Луганськ 24», інформацію про який можна знайти на сайті «Державного телебачення i радіомовлення ЛНР» («Державна телевізійна..», 2020). Існують й суто місцеві канали, наприклад, у м. Красний Луч (Хрустальний) мовить телеканал «ТРК Красний Луч», в Антрациті - «Антел-плюс Антрацит», в Алчевську - «Аскет» та ін. Місцеві канали висвітлюють, загалом, новини культури, музики, спорту і транслюють оголошення людей стосовно купівлі/продажу тощо.

Окрім телебачення терористичні угрупування «ЛДНР» провели певні зміни на радіо. Наприклад, якщо у 2017 р. на окупованих територіях інколи можна було почути українське радіо «Люкс ФМ», то зараз воно відсутне взагалі. Водночас у так званій «ДНР» заговорили такі радіостанції, як: «Радіо «Республіка», «Радіо «Столиця», «Радіо ТВ», «Татове радіо» («ЗМІ ДНР»..., 2020). А в «ЛНР» - «Радіо «Перемога», «Своє радіо», «Радіо «Республіка» та «Вести плюс. Луганск» («Державна телевізійна..», 2020). Вони розповідають про новини в «ЛДНР» та світі. Варто звернути увагу, що зранку там вмикають гімни «республік» або Радянського Союзу. Також, присутнє і російське радіо («Авторадіо», «Шансон» і т. д.).

Основним джерелом альтернативних новин про події в регіоні та Україні, для мешканців окупованих територій, $є$ інтернет й так зване «сарафанне радіо». В інтернеті, це 
інформаційні сайти «ОстроВ», «Новости Донбасса», Громадське телебачення Донбасу, та пабліки в соцмережах. Зокрема, з 22 по 26 квітня 2019 р. IMI проаналізував контент семи онлайн-видань, що функціонують у непідконтрольних Україні районах Донецької та Луганської областей (ОРДЛО). Дослідження стосувалося висвітлення української, російської та влади самопроголошених республік, кількості опублікованих фейків та мови ворожнечі. Унаслідок чого з'ясувалося, що в регіональних ЗМІ ОРДЛО 20\% інформації стосувалося саме української влади, 19,5\% - самопроголошеної влади так званої «ЛДНР», 9\% - російської влади. При цьому слід відзначити, що український політикум висвітлений переважно в негативному ключі, а місцевий та російський - у позитивному (Терещенко, 2020).

Водночас не слід вилучати з поля зору групи у соціальних мережах, які стають 3 року в рік популярнішими й можуть слугувати потужним мобілізаційним ресурсом для місцевих очільників. Зокрема, варто звернути увагу на групу ВКонтакте «Типичний Донецк», яка нараховує 408 тисяч учасників і $\epsilon$ найбільшим місцевим пабліком з усіх регіонів. Контент групи швидше неполітизований, але певною мірою про«регіональний», типовий для ЗМІ неокупованої території Донецької області. Ця група пов'язана $з$ вебсайтом місцевих новин «Это Донецк», який подає інформацію про події на окупованій території, але певною мірою поблажливо до проросійської позиції (Дослідження медіа-ситуації..., 2020). В «ЛНР» розповсюджені такі групи ВКонтакте, як «Луганск 1 Новости | ЛНР», «Другой Луганск», «Луганск - наш город» та ін. Наприклад, група «Луганск 1 Новости | ЛНР» налічує 144428 тисяч учасників. В ній так само розповідається про спорт, культуру, політику й інші події «республіки». Не менш вагомою є група «Сводки от ополчения Новороссии», яка налічує 433940 тисяч учасників і $є$ найвпливовішою серед місцевих жителів. Висвітлює новини про обстріли, політику, гуманітарну ситуацію та збирає гроші з людей на допомогу 
«армії ЛДНР» («Сводки от ополчения...», 2020). Почали 3'являтися групи у соцмережах Facebook, Вконтакте, де жителі різних населених пунктів, у яких тривають бої, повідомляють про обстріли. Там також розміщують передруки оголошень «міністерств» псевдореспублік. Серед повідомлень місцевих жителів бувають важливі й правдиві. Але перевірити їх інколи складно.

Крім новин, на місцевих пабліках можна знайти розклад руху транспорту, інформацію про роботу різних «установ ЛДНР». 2014-2015 року там також розміщували інформацію про зниклих безвісти. С пабліки, де публікують інформацію про злочини на окупованих територіях та резонансні події в ОРЛО. Зокрема, пабліки Вконтакте «Свердловск - ты должен это знать» та «Другой Луганск».

Водночас відзначимо, що кількість проукраїнських груп в соціальних мережах значно зменшилась у порівнянні з 20142016 рр. Якщо в перші два-три роки війни місцеві жителі не боялись створювати проукраїнські пабліки, збиратись в гуртки, поширювати українську символіку на державних будівлях «ЛДНР», то зараз ця практика майже відсутня. Це обумовлено, перш за все, посиленням контролю бойовиками за суспільством в інформаційному просторі, у тому числі й за допомогою Telegtam-каналів, груп ВКонтакте та інших ресурсів, через які вони аналізують реакцію жителів на ті чи інші новини, провокують і маніпулюють їх настроями. Своєю чергою це накладає негативний відбиток на місцевий соціум, адже на окупованих територіях поступово формується почуття страху та вороже ставлення до України.

Цьому значно сприяє й те, що інформаційне наповнення сайтів ОРДЛО здебільшого перенасичене дописами присвяченими обстрілам, «небажання України йти до миру» тощо. Загалом дезінформація про війну є доволі стабільною темою саме тому, що там $є$ обмежене коло авторів, які працюють на проросійські українські медіа або на російські чи підконтрольні Кремлю. Хоча, варто зазначити, що тема війни 
дуже рідко приваблює маніпуляції та дезінформацію на українських «сміттєвих» сайтах. Для них це, як правило, табу, хіба що мова йде про «джинсу» на користь проросійських сил або чиїсь передруковані думки. Це важливе питання, щодо якого є консенсус (Днєпровська, 2020).

Окрім цих ресурсів бойовики Луганська й Донецька створили власні інформ-центри: Луганськінформцентр, та ДАН (Донецьке агентство новин). Ці два інтернет-видання - головні пропагандистські майданчики. Обидва сайти заблоковані українськими провайдерами, адже тут публікується «офіційна» інформація угруповань «ЛДНР», котра є прямим порушенням українського законодавства. Також існують сайти так званих «держустанов ОРДЛО». Попри те, що вони є невизнаними місцеве населення живе за цими «законами», а також користується інформацією з цих сайтів під час відвідування родичів або з інших причин (Троян, 2018). Таких сайтів існує приблизно 14-15 (не враховуючи окремі сайти «Міністерств ЛДНР» або їх «комітетів»): «Офіційний сайт глави ЛНР/ДНР», «Народна Рада ЛНР/ДНР», «Рада Міністрів ЛНР/ДНР», «Державний комітет статистики ЛНР/ДНР», «Державний комітет податків і зборів ЛНР/ДНР», «Державний митний комітет ЛНР/ДНР» тощо. Наприклад, на сайті так званої «Народної Ради ЛНР» можна знайти інформацію про законодавство, законодавчу, депутатську i міжнародну діяльність тощо. Існує «Комітет Народної Ради ЛНР з питань міжнародних відносин, зв'язку, інформаційної й масових комунікацій». Ось що вказано про комітет на сайті «Народної Ради ЛНР»: «...здійснює дипломатичні та консультаційні відносини Луганської Народної Республіки 3 іноземними державами та міжнародними організаціями, що сприяє взаємному партнерству і співпраці; розробляє і вносить на розгляд Ради законопроекти про засоби масової інформації; розробляє і ратифікує міжнародні угоди, а також здійснює контроль за їх виконанням...» («Комітет Народної Ради...», 2020). На іншому сайті «ЛНР» можна знайти інформацію про 
3MI, акредитовані в «ЛНР», такі, як: «Державна телерадіокомпанія ЛНР», «Луганський інформаційний центр», «Молодіжне інформаційне агентство «Істок»», «Газета «Життя Луганська»» («Міністерство економічного...», 2020). На «офіційному сайті ДНР» так само є інформація про: «главу ДНР», «уряд», «Народну Раду», «Верховний суд» i «Генеральну прокуратуру». Розміщено їх контактну і довідкову інформацію, а також розповідається про «символіку і гімн ДНР» («ЗМІ ДНР»..,, 2020). Стосовно регулювання інформаційної політики в «ДНР», то цим там займається «Комітет Народного уряду по зовнішній політиці, міжнародним зв'язкам, інформаційній політиці та інформаційним технологіям». До компетенції цього комітету входить багато питань, ключовими 3 яких є: «...підготовка проєктів законів 3 видавницької діяльності й функціонування друкованих й електронних 3МI; інформації, доступу до інформації, захисту інформації й порядку іï використання; зовнішньої й інформаційної політики ДНР...» («Комітет Народної Ради..., 2020).

Варто зазначити, що деякі з аналізованих нами соцмереж є заблокованими на підконтрольній території України згідно 3 указом від 26 квітня 2017 р. «Про застосування персональних спеціальних економічних та інших обмежувальних заходів (санкцій)», що був неодноразово продовжений 3 метою гарантування національної безпеки (Про застосування персональних..., 2020). 32014 р. під забороною перебувають й офіційні сайти так званих «держустанов ЛДНР». Тому, для аналізу інформації на цих сайтах ми скористалися спеціальною програмою VPN, яка дозволяє змінювати геолокацію в браузері, або перебуваючи безпосередньо на непідконтрольній території.

Важливо відзначити, що окрім так званих держустанов кожна з «республіка» має власну законодавчу базу регулювання інформаційної сфери. Наприклад, на території так званої «ДНР» діє «Закон про засоби масової інформації» від 29 червня 
2015 p. У ст. 5 цього закону зазначено, що: «... законодательство Донецкой Народной Республики о средствах массовой информации основывается на Конституцчии Донецкой Народной Республики, состоит из настоящуего Закона и издаваемых в соответствии с ним иных нормативных правовых актов Донецкой Народной Республики. При введении на территории Донецкой Народной Республики особых правовых режимов, деятельность средств массовой информации регулируется настоящим Законом, а также Законом Донеикой Народной Республики от 24.03.2015 года № 23-ІНС «Об особых правовых режимах» ...» тощо («Закон ДНР...», 2020).

Цікавим для дослідження є й так званий «наказ №32 Міністерства інформації ДНР» від 15 січня 2015 р. «Про правила отримання акредитації для роботи на території ДНР представниками 3МI й нової форми акредитованого посвідчення», де показані зразки посвідчення та вказані правила роботи журналістів по висвітленню бойових дій («О правилах получения..., 2020). Хоча насправді цей наказ є більш декларативним, ніж реальним.

Якщо зайти на сайт так званої «Народної Ради ЛНР», можна знайти інформацію про наявні закони, які регулюють роботу 3МІ (в тому числі й друкованих): «Закон про рекламу» від 7 квітня 2017 р.; «Про забезпечення доступу до інформації про діяльність державних органів й органів місцевого самоврядування» від 14 червня 2019 р.; «Про порядок висвітлення діяльності органів державної влади в державних засобах масової інформації» від 27 травня 2016 р.; «Про засоби масової інформації» від 7 листопада 2014 р. («Класифікатор законів..., 2020). Наприклад, в главі III ст.27 так званого «Закону про засоби інформації» зазначено наступне: «... Воспрепятствование осуществляемому на законном основании распространению продукции средств массовой информации со стороны граждан, объединений граждан, должностных лии, предприятий, учреждений, организаций, государственных 
органов - не допускается. Распространение продукции средства массовой информации считается коммерческим, если за нее взимается плата...» тощо. В ст.30 пишеться, що: «... тираж периодического печатного издания, аудио-, видео-, кинохроникальной программы определяется главным редактором по согласованию с издателем...». Також є ст.53 «Обов'язкові повідомлення», де сказано про те, що «... редакции средств массовой информации, учредителями (соучредителями) которых являются государственные органы, обязаны публиковать по требованию этих органов их официальные сообщения в порядке, регулируемом уставом редакции или заменяющим его договором, а равно иные материаль, публикация которых в данных средствах массовой информации предусмотрена законодательством ЛНР ...» та ін. Цікавим є пункт в ст. 72 «Поширення зарубіжної інформації» про те, що: «..гражданам ЛНР гарантируется беспрепятственный доступ к сообщениям и материалам зарубежных средств массовой информации...». При тому, помітити якусь закордонну газету практично неможливо («Закон «Про засоби...», 2020).

Усього на окупованій території Луганської області видається 35 газет, з них 14 підконтрольні «міністерству». Такі видання фінансуються в рамках «Програми підтримки державних друкованих засобів масової інформації», схваленої «радою міністрів ЛНР». У рамках програми «міністерство» укладає договори з редакціями газет на висвітлення діяльності «органів державної влади ЛНР». За даними групи «Інформаційний спротив», фінансування друкованих 3МI для потреб «ЛНР», станом на 2016 р., коштувало не менше 16 млн рублів на рік (близько 6 млн грн) (Український центр..., 2019 : 60).

В «ЛДНР» виходить чимало газет, здебільшого безкоштовних. У їх числі: «Голос Республики», «Дебальцевские вести», «Донецк вечерний», «Знамя Победы», «Кочегарка ДНР», «Наше время», «Новая жизнь», «Родина», 
«Родное Приазовье», «Восточный курьер», «Голос Донбасса», «Советская Луганщина», «Республика», «Жизнь Луганска», «Общественно-политический еженедельник «Вечерний Луганск»», «Молодогвардеец» та інші («ЗМІ ДНР»..., 2020; Довідник Луганська..., 2021). Місцеве проукраїнське видання Луганська «Реальна газета» виходило майже до середини липня 2014 року. Останній друкований випуск не вийшов у продажгазетні кіоски перестали працювати, до міста вже не завозили пресу (Троян, 2018).

Загалом слід зауважити, що у 2014-2015 рр. друковані ЗМІ «ЛДНР» пройшли перехідний етап до створення нової пропагандистської машини. Слід звернути увагу, що в усіх газетах «ЛДНР» не публікуються статті українською мовою. Проте, інколи можна побачити українські цитати написані російськими літерами. Аналізуючи контекст фотографій, які друкуються на перших сторінках газет, можна зробити висновок, що більшість фотографій - це «глави республік», а вже на інших - фотографії побутового характеру (інфраструктурних об'єктів, благоустрою територій тощо). Також зображені різного роду культурні події: змагання, вистави, концерти та ін. На останніх сторінках газети можна побачити різноманітні оголошення з приводу роботи, гороскоп, рекламу та рубрику «продам/куплю». Якщо це звичайна місцева газета, то в ній є також програма для телебачення.

У ході дослідження нашу увагу привернула газета «Красний Луч», яка є місцевою газетою м. Красний Луч (нині Хрустальний) Луганської області (підконтрольної «ЛНР») і зазвичай вона є однотипною («Газета Красний Луч...», 2021). Випуск даної газети №51 від 17 грудня 2020 p., а рекомендована ціна складає 17 рублів. Тираж - 4650 тис. Видається з вересня 1920 року. На першій сторінці розміщений портрет «глави ЛНР» Леоніда Пасічника та портрет «голови уряду ЛНР» Сергія Козлова, де розташовані їх звернення до т. зв. «Дня співробітника органів державної безпеки». Зверху, над назвою газети, розташовані назви основних статей. Їх тут 7 : 
«Освітній форум \#ГУRU - можливість розкрити потенціал й принести користь своїй Республіці», «ЧСПК дозволила проведення планових перевірок», «Бізнес і уряд ЛНР повинні взаємодіяти», «УТіСЗН починає видачу новорічних подарунків», «Мужність. Відвага. Героїзм», «Вшанування ліквідаторів ЧАЕС», «Атом збісився, вгору кинувся, і почалась війна».

Знизу інформація про конкурси в «ЛНР» («Диво новорічної іграшки»; «3 Новим Роком, солдат!»). Звертаючи увагу на конкурс «3 Новим Роком, солдат!», який стартував 15 грудня слід наголосити, що його організатором виступив проєкт «Волонтер» суспільного руху «Мир Луганщини». Суть конкурсу полягала у малюнках: «На рисунках должны быть пожелания для военнослужащих и поздравления с Новым Годом. Работы победителей конкурса и участников передадут военнослужащим Народной милиции ЛНР, которые находятся на передовых позициях». Особливість цього конкурсу полягає у прищеплюванні любові дітей до «ополченців ЛНР» (Красный Луч..., 2020). Поруч з інформацією про конкурси видно уривок статті про встановлення 180 нових контейнерів для складування відходів. Особливу увагу слід звернути на кольорову гаму газети. Так, 1 сторінка газети надрукована у червоних, блакитних, синіх і чорних кольорах, тоді як інші сторінки чорно-білі (окрім 12-13). Разом з основними статтями на сторінках є стаття «Пам'яті воєнкорів..» (2 сторінка; розповідається про те, що «глава ЛНР» вшанував пам'ять загиблих журналістів), «Пам'ятка для громадян ЛНР» (де висвітлено про те, що потрібно для отримання громадянства ЛНР або РФ), стаття «Новорічний кубок по міні-футболу 2020 року» (5 стор.). На сторінці 4 подається інформація про відновлення вуличного світла в селищах Софієвський та Запоріжжя. На шостій сторінці розповідається про «Особливості призначення пенсії багатодітним матерям й матерям дітей-інвалідів», про першу допомогу при обмороженні, про профілактику отруєння чадним газом й 
першу допомогу. Далі йде програма для телебачення. Саме там можна знайти про те, що ж дивляться на окупованих територіях. Сторінки 9-11 присвячені 75-річчю Перемоги, історіям про радянських солдатів та їх родини. У 12-13 сторінках йдеться про пам'ятні дати (зокрема, про День вшанування учасників ліквідації атомної аварії на Чорнобильській АЕС). 14 стор. - «Актуальні питання у сфері охорони атмосферного повітря на території ЛНР», а у 15 стор. мовиться про релігію. 16 стор. займає: «Пам’ятка про пожежну безпеку в зимовий пожежно небезпечний період», «Профілактичні рейди у водойм з метою попередження про небезпеку виходу на тонкий лід», «На території Республіки проводяться заходи з профілактики й недопущення порушення обороту піротехнічних виробів» і колонка під назвою «Виражаємо скорботу». На 18 сторінці закінчується програма для ТБ і починаються оголошення по типу «Куплю/продам», реклама, оголошення про роботу, вдячності, гороскоп, рецепти їжі, а на останній сторінці вітання 3 Днем народження (Красный Луч..., 2020).

Отже, запропонований аналіз свідчить про те, що упродовж останніх п’яти років на непідконтрольних Україні територіях Луганської та Донецької областей намітились тривожні тенденції у медіапросторі. Їх суть полягає у тому, що поступово були витіснені українські канали подачі інформації, які були замінені на так звані місцеві або російські, покликані закріпити ціннісно-світоглядні наративи РФ на цих територіях. Про це зокрема свідчить псевдозаконодавство створене терористами «ЛДНР», унаслідок закріплення якого суспільство опинилось в складній ситуації, коли будь-яке слово чи думка опиняються під контролем т. зв. «МДБ ЛДНР», а за кожним постом, твітом чи статтею слідкують «органи державної влади ЛДНР». Примітно, що окрім залякування населення (про так званих «шпигунів» й «агентів» СБУ) та відновлення ностальгії за Радянським Союзом, одним із головних завдань 3МI на непідконтрольних Україні територіях є тотальне витіснення 
будь-якого україномовного контенту, який водночас є потужним стрижнем національної ідентичності й самосвідомості. 3 цією метою, перевага надається лише газетам і журналам з Росії.

Загалом аналіз медіа та ЗМІ окупованих територій, свідчить, що вони несуть суттєву загрозу для втрати свідомої частини громадян України, а також формування в них нового світогляду. 3 урахуванням того, що українські владні важелі відсутні в «ЛДНР», то відновити викривлений світогляд людей буде вкрай складно.

\section{ДЖЕРЕЛА ТА ЛІТЕРАТУРА}

1. «Газета Красний Луч. ЛНР»: веб-сайт. URL: https://redraylnr-news.su/ (дата звернення: 2.01.2021).

2. «Державна телевізійна і радіомовна компанія ЛНР»: вебсайт. URL: https://gtrklnr.com/ (дата звернення: 22.12.2020).

3. «Закон «Про засоби масової інформації» від 7.11.2014 р. «Народна Рада ЛНР»: веб-сайт. URL: https://www.nslnr.su/zakonodatelstvo/normativno-pravovayabaza/906/ (дата зернения: 30.12.2020).

4. «Закон ДНР «Про засоби масової інформації»» від 29.06.2015 р. «Народна Рада ДНР»,: веб-сайт. URL: https://dnrsovet.su/zakon_doneckoj_narodnoj_respubliki_o_sredstv ah_massovoj_informacii// (дата звернення: 29.12.2020).

5. «ЗМІ ДНР». «Офіиійний сайт ДНР»: веб-сайт. URL: https://dnronline.su/sredstva-massovoi-informatsii-dnr/ (дата звернення: 20.12.2020).

6. «Класифікатор законів по сферам регулювання суспільних відносин». «Народна Рада ЛНР»: веб-сайт. URL: https://www.nslnr.su/zakonodatelstvo/klassifikator-zakonov/ (дата звернення: 29.12.2020).

7. «Комітет Народної Ради ЛНР 3 питань міжнародних відносин, зв'язку, інформаційної політики і масових комунікацій». «Народна Рада ЛНР»: веб-сайт. URL: https://www.nslnr.su/about/komitety/335/ (дата звернення: 27.12.2020). 
8. «Комітет Народної Ради по зовнішній політиці, міжнародним зв'язкам, інформаційній політиці й інформаційним технологіям». «Народна Рада ДНР»: веб-сайт. URL: https://dnrsovet.su/struktura/komitety-i-komissii-ns/komitetnarodnogo-soveta-po-vneshnej-politike-mezhdunarodnym-svyazya m-informatsionnoj-politike-i-informatsionnym-tehnologiyam/ (дата звернення: 27.12.2020).

9. «Міністерство економічного розвитку ЛНР»: веб-сайт. URL: https://merlnr.su/docs/ (дата звернення: 27.12.2020).

10. «О правилах получения аккредитации для работы на территории ДНР представителями СМИ и новой форме аккредитационного удостоверения». «Приказ Министерства Информации Донеикой Народной Республики» №32 от 15.01.2015. https://dnronline.su/prikazy-ministerstva-informaciidoneckoj-narodnoj-respubliki/ (дата звернення: 29.12.2020).

11. «Сводки от ополчения Новороссии»: веб-сайт. URL: https://vk.com/strelkov_info (дата звернення: 25.12.2020).

12. Голуб О. Фейки та мова ворожнечі: як висвітлюють Україну в медіа окупованих території Донбасу. Інститут масової інформаиії, 21.05.2019 р.: веб-сайт. URL: https://imi.org.ua/articles/feyky-ta-mova-vorozhnechi-iakvysvitliuiut-ukrainu-v-media-okupovanykh-terytoriy-donbasu-i47/ (дата звернення: 20.12.2020).

13. Громадська організація «Громадський холдинг «Група впливу»»»: веб-сайт. URL: https://www.vplyv.org.ua/ (дата звернення: 17.12.2020).

14. Днєпровська М. Як проросійські ЗМІ брешуть про Донбас (інтерв'ю з журналісткою, яка знається на фейках). Вільне радіо, 11.08.2020 р.: веб-сайт. URL: https://freeradio.com.ua/iak-prorosiiski-zmi-breshut-pro-donbasinterv-iu-z-zhurnalistkoiu-iaka-znaietsia-na-feikakh/

(дата звернення: 25.12.2020).

15. Довідник Луганська: веб-сайт. URL: https://lugansk.yaspravka.com/redaktsii-gazet-i-zhurnalov (дата звернення: 2.01.2021). 
16. Дослідження медіа-ситуації на Сході і Півдні України: Донецька область. Інститут масової інформаиї, 11.03.2016 р.: веб-сайт. URL: https://imi.org.ua/articles/doslidjennya-mediasituatsiji-na-shodi-i-pivdni-ukrajini-donetska-oblast-i545 (дата звернення: 23.12.2020).

17. Інститут масової інформації: веб-сайт. URL: https://imi.org.ua/ (дата звернення: 19.12.2020).

18. Інформаційні чинники системи інтеграторів Донбасу i Криму в загальноукраїнській єдності : монографія / В. М. Горовий, О. С. Онищенко, М. Б. Закіров, А. В. Матвійчук, Ю. М. Половинчак, С. В. Полтавець, С. В. Горова, В. І. Попик. Київ: НБУВ, 2016. 202 с.

19. Красный Луч. Газета. № 51 (13037), 17 декабря 2020. $18 \mathrm{c}$.

20. Міністерство з питань реінтеграції тимчасово окупованих територій України: веб-сайт. URL: https://www.mtot.gov.ua/ (дата звернення: 19.12.2020).

21. Міністерство інформаційної політики України: веб-сайт. URL: https://mip.gov.ua/ (дата звернення: 17.12.2020).

22. Національній інститут стратегічних досліджень: веб-сайт. URL: https://niss.gov.ua/ (дата звернення: 17.12.2020).

23. Про застосування персональних спеціальних економічних та інших обмежувальних заходів (санкцій). Рішення РНБО від 27 квітня 2017. Верховна Рада України, Законодавство України: веб-сайт. URL: https://zakon.rada.gov.ua/laws/show/n0004525-17\#Text (дата звернення: 27.12.2020).

24. Терещенко О. Про що пишуть ЗМІ окупованих територій - дослідження Інституту масової інформації. Європростір, 04.06.2019: веб-сайт. URL: https://eprostir.org/2019/06/04/proshcho-pyshut-zmi-okupovanykh-terytorii-doslidzhennia-imi/ (дата звернення: 22.12.2020).

25. Троян В. Новини окупаційних 3МI: чому і як варто їх читати. Громадське радіо, 27.11.2018 р.: веб-сайт. URL: https://hromadske.radio/vlasna-dumka/novyny-okupaciynyh-zmichomu-i-yak-yih-varto-chytaty (дата звернення: 27.12.2020). 
26. Український центр економічних і політичних досліджень імені Олександра Разумкова. Національна безпека і оборона, 2019, №1-2(177-178). C. 56-61. URL: https://razumkov.org.ua/ uploads/ journal/ukr/NSD177-178_2019_ukr.pdf(дата звернення: 30.12.2020).

27. Центр Разумкова: веб-сайт. URL: https://razumkov.org.ua/ (дата звернення: 23.12.2020).

\section{REFERENCES}

1. «Hazeta Krasnyi Luch. LNR»: veb-sait [«The newspaper Krasny Luch. LNR»: website]. Retrieved from https://redray-lnrnews.su/ (data zvernennia: 2.01.2021).

2. «Derzhavna televiziina i radiomovna kompaniia LNR»: vebsait [«State Television and Radio Broadcasting Company of the Luhansk People's Republic»: website]. Retrieved from https://gtrklnr.com/ (data zvernennia: 22.12.2020).

3. «Zakon «Pro zasoby masovoi informatsii» vid 7.11.2014 [Law «On Mass Media» of November 7. 2014]. «Narodna Rada LNR»: veb-sait [«People's Council of the Luhansk People's Republic»: website]. Retrieved from https://www.nslnr.su/ zakonodatelstvo/normativno-pravovaya-baza/906/ (data zernenyia: 30.12.2020).

4. «Zakon DNR «Pro zasoby masovoi informatsii»» vid 29.06.2015 [«Law of the DPR» On Mass Media «of June 29. 2015»]. «Narodna Rada DNR»: veb-sait. [«People's Council of the DPR»: website.]. Retrieved from https://dnrsovet.su/ zakon_doneckoj_narodnoj_respubliki_o_sredstvah_massovoj_infor macii/ (data zvernennia: 29.12.2020).

5. «ZMI DNR» [«DPR media»]. «Ofitsinyi sait DNR»: vebsait. [«Official site of the DPR»: website]. Retrieved from https://dnronline.su/sredstva-massovoi-informatsii-dnr/ (data zvernennia: 20.12.2020).

6. «Klasyfikator zakoniv po sferam rehuliuvannia suspilnykh vidnosyn» [«Classifier of laws on the regulation of public relations»]. «Narodna Rada LNR»: veb-sait [«People's Council of 
the Luhansk People's Republic»: website]. Retrieved from https://www.nslnr.su/zakonodatelstvo/klassifikator-zakonov/ (data zvernennia: 29.12.2020).

7. «Komitet Narodnoi Rady LNR z pytan mizhnarodnykh vidnosyn, zv'iazku, informatsiinoi polityky i masovykh komunikatsii» [Committee of the People's Council of the People's Republic of China on International Relations, Communications, Information Policy and Mass Communications]. «Narodna Rada LNR»: veb-sait. [People's Council of the People's Republic of China]. Retrieved from https://www.nslnr.su/about/komitety/335/ (data zvernennia: 27.12.2020).

8. «Komitet Narodnoi Rady po zovnishnii politytsi, mizhnarodnym zv'iazkam, informatsiinii politytsi y informatsiinym tekhnolohiiam» [«Committee of the People's Council of the Luhansk People's Republic on International Relations, Communications, Information Policy and Mass Communications»]. «Narodna Rada DNR»: veb-sait [«People's Council of the Luhansk People's Republic»: website.]. Retrieved from https://dnrsovet.su/struktura/komitety-i-komissii-ns/komitetnarodnogo-soveta-po-vneshnej-politike-mezhdunarodnym-svyazya m-informatsionnoj-politike-i-informatsionnym-tehnologiyam/ (data zvernennia: 27.12.2020).

9. «Ministerstvo ekonomichnoho rozvytku LNR»: veb-sait [ «Ministry of Economic Development of the Luhansk People's Republic»: website]. Retrieved from https://merlnr.su/docs/ (data zvernennia: 27.12.2020).

10. «O pravylakh poluchenyia akkredytatsyy dlia rabotы na terrytoryy DNR predstavyteliamy SMY y novoi forme akkredytatsyonnoho udostoverenyia» [«On the rules for obtaining accreditation for work on the territory of the DNR by media representatives and a new form of accreditation certificate»]. «Prykaz Mynysterstva Ynformatsyy Donetskoi Narodnoi Respublyky». [ «Order of the Ministry of Information of the Donetsk People's Republic»]. 32. 15.01.2015. Retrieved from https:// dnronline.su/prikazy-ministerstva-informacii-doneckoj-narodnojrespubliki/ (data zvernennia: 29.12.2020). 
11. «Svodky ot opolchenyia Novorossyy»: veb-sait. [«Summaries of the Novorossiya militia»: website]. Retrieved from https://vk.com/strelkov_info (data zvernennia: 25.12.2020).

12. Holub O. Feiky ta mova vorozhnechi: yak vysvitliuiut Ukrainu v media okupovanykh terytorii Donbasu [Fakes and hate speech: how Ukraine is covered in the media in the occupied territories of Donbass]. Instytut masovoi informatsii [Institute of Mass Information]. 21.05.2019. Retrieved from https://imi.org.ua/ articles/ feyky-ta-mova-vorozhnechi-iak-vysvitliuiut-ukrainu-vmedia-okupovanykh-terytoriy-donbasu-i47/ (data zvernennia: 20.12.2020).

13. Hromadska orhanizatsiia «Hromadskyi kholdynh «Hrupa vplyvu»»»: veb-sait [Public organization «Public Holding» Group of Influence»: website]. Retrieved from https://www.vplyv.org.ua/ (data zvernennia: 17.12.2020).

14. Dnieprovska M. Yak prorosiiski ZMI breshut pro Donbas (interv'iu z zhurnalistkoiu, yaka znaietsia na feikakh) [How proRussian media lie about Donbass (interview with a journalist who knows fakes)]. Vilne radio: veb-sait [Free radio: website]. 11.08.2020. Retrieved from https://freeradio.com.ua/iak-prorosiiskizmi-breshut-pro-donbas-interv-iu-z-zhurnalistkoiu-iaka-znaietsia-n a-feikakh/ (data zvernennia: 25.12.2020).

15. Dovidnyk Luhanska: veb-sait [Directory of Luhansk: website]. Retrieved from https://lugansk.yaspravka.com/redaktsiigazet-i-zhurnalov (data zvernennia: 2.01.2021).

16. Doslidzhennia media-sytuatsii na Skhodi i Pivdni Ukrainy: Donetska oblast. [Research of the media situation in the East and South of Ukraine: Donetsk region]. Instytut masovoi informatsii, veb-sait [Institute of Mass Information]. 11.03.2016. Retrieved from https://imi.org.ua/articles/doslidjennya-media-situatsiji-na-shodi-ipivdni-ukrajini-donetska-oblast-i545 (data zvernennia: 23.12.2020).

17. Instytut masovoi informatsii: veb-sait [Institute of Mass Media: website]. Retrieved from https://imi.org.ua/ (data zvernennia: 19.12.2020). 
18. Informatsiini chynnyky systemy intehratoriv Donbasu i Krymu v zahalnoukrainskii yednosti (2016). [Information factors of the system of integrators of Donbass and Crimea in all-Ukrainian unity] : monohrafiia [monograph]. / V. M. Horovyi, O. S. Onyshchenko, M. B. Zakirov, A. V. Matviichuk, Yu. M. Polovynchak, S. V. Poltavets, S. V. Horova, V. I. Popyk. Kyiv: NBUV, 202.

19. Krasnyi Luch [Krasnyi Luch]. Hazeta [Newspaper]. 51 (13037), 17.12.2020. 18.

20. Ministerstvo z pytan reintehratsii tymchasovo okupovanykh terytorii Ukrainy: veb-sait [Ministry of Reintegration of the Temporarily Occupied Territories of Ukraine: website]. Retrieved from https:/www.mtot.gov.ua/ (data zvernennia: 19.12.2020).

21. Ministerstvo informatsiinoi polityky Ukrainy: veb-sait [Ministry of Information Policy of Ukraine: website]. Retrieved from https://mip.gov.ua/ (data zvernennia: 17.12.2020).

22. Natsionalnii instytut stratehichnykh doslidzhen: veb-sait [National Institute for Strategic Studies: website]. Retrieved from https://niss.gov.ua/ (data zvernennia: 17.12.2020).

23. Pro zastosuvannia personalnykh spetsialnykh ekonomichnykh ta inshykh obmezhuvalnykh zakhodiv (sanktsii) [On the application of personal special economic and other restrictive measures (sanctions)]. Rishennia RNBO vid 27 kvitnia 2017. [Decision of the National Security and Defense Council of April 27, 2017]. Verkhovna Rada Ukrainy, Zakonodavstvo Ukrainy: veb-sait [Verkhovna Rada of Ukraine, Legislation of Ukraine: website]. Retrieved from https://zakon.rada.gov.ua/laws/show/n000452517\#Text (data zvernennia: 27.12.2020).

24. Tereshchenko O. Pro shcho pyshut ZMI okupovanykh terytorii - doslidzhennia Instytutu masovoi informatsii [What the media of the occupied territories write about - a study by the Institute of Mass Information]. Yevroprostir: veb-sait [Eurospace, June 4, 2019: website]. 04.06.2019. Retrieved from https:// eprostir.org/ 2019/06/04/ pro-shcho-pyshut-zmi-okupovanykhterytorii-doslidzhennia-imi/ (data zvernennia: 22.12.2020). 
25. Troian V. Novyny okupatsiinykh ZMI: chomu i yak varto yikh chytaty [News of the occupation media: why and how to read them]. Hromadske radio: veb-sait [Public Radio: website]. 27.11.2018. Retrieved from https://hromadske.radio/vlasna-dumka/novynyokupaciynyh-zmi-chomu-i-yak-yih-varto-chytaty (data zvernennia: 27.12.2020).

26. Ukrainskyi tsentr ekonomichnykh i politychnykh doslidzhen imeni Oleksandra Razumkova [Ukrainian A. Razumkov Center for Economic and Political Studies]. Natsionalna bezpeka i oborona [National Security and Defense]. 2019. 1-2(177-178). 56-61. Retrieved from https://razumkov.org.ua/ uploads/journal/ ukr/NSD177-178 2019 ukr.pdf (data zvernennia: 30.12.2020).

27. Tsentr Razumkova: veb-sait [Razumkov Center: website]. Retrieved from https://razumkov.org.ua/ (data zvernennia: 23.12.2020).

\section{АНОТАЦІЯ}

3 огляду на сучасне геополітичне становище Украӥни та інформаційно-комунікаційні виклики з боку Росї, яка веде окупаційно-гібридну війну проти нашої держави, особливу увагу потрібно звернути на формування світогляду населення на непідконтрольних Україні територіях Луганської та Донеиької областей через медіа у 2014-2020 р. Важливу роль у формуванні російського світогляду населення на непідконтрольних Украӥні територіях відіграють медіа так званих «ЛНР» та "ДНР», які діють за допомогою методів тотальної пропаганди, залякування та маніпулювання. Засоби масової інформації невизнаних республік Російська Федерація ефрективно використовує як інструмент впливу на інформаційний та економічний простори окупованих mериторій.

У даному огляді автори розкривають зміни, щзо відбулися у циифровому медіапросторі й друкованих ЗМI після 2014 року на непідконтрольних Украӥні територіях. Визначено вплив місиевих мас медіа на формування світогляду населення Луганської та Донеиької областей. 
3'ясовано, щзо упродовж останніх п'яти років на непідконтрольних Украӥні територіях Луганської та Донецької областей були витіснені практично усі українські канали подачі інформачії. Їх замінили російські, або проросійські місиеві мас-медіа, метою яких була пропаганда иіннісносвітоглядних наративів "русского міра» на ичих територіях.

Доведено, щзо населення Луганської та Донецької областей фактично опинилося в інформачійному вакуумі, за кожним постом, твітом чи статтею слідкують «органи державної влади ЛДНР». У пунктах продажу преси відсутні украӥнські газети й журнали, водночас переважають російські друковані 3МI.

Визначено, щзо у місцевих жителів на непідконтрольних територіях итучно формують почуття страху до політики Украӥнської держави. $У$ місиевій пресі насамперед публікуються статті про «шпигунів» й «агентів» СБУ, а також, створюється ностальгія за Радянським Союзом, иляхом героїзачї безвісти зниклих солдатів «Великої Вітчизняної війни».

Ключові слова: Україна, Російська Федерачія, «гібридна війна», «русский мир», непідконтрольні території, мас-медіа, преса, ЗМІ, ЛДНР, ЛНР (Луганська народна республіка), ДНР (Донецька народна республіка).

\section{АННОТАЦИЯ}

Учитывая современное геополитическое положение Украины и информационно-коммуникационные вызовы со стороны России, которая ведет оккупационно-гибридную войну против нашего государства, особое внимание нужно обратить на формирование мировоззрения населения на неподконтрольных Украины территориях Луганской и Донецкой областей через медиа в 2014-2020 г.. Важную роль в формировании русского мировоззрения населения на неподконтрольных Украины территориях играют медиа так называемых «ЛНР» и «ДНР», которые действуют с помощью 
методов тотальной пропаганды, запугивания и манипулирования. Средства массовой информации непризнанных республик Российская Федерация эффективно использует как инструмент влияния на информационное и экономическое пространство оккупированных территорий.

В данном обзоре авторы раскрывают изменения, произошедшие в цифровом медиапространстве и печатных СМИ после 2014 года на неподконтрольной Украине территории. Определено влияние местных масс-медиа на формирование мировоззрения населения Луганской и Донецкой областей.

Установлено, что на протяжении последних пяти лет на неподконтрольной Украине территории Луганской и Донецкой областей были вытеснены практически все украинские каналы подачи информации. Их заменили русские, или пророссийские местные СМИ, целью которых была пропаганда ценностномировоззренческих нарративов «русского мира» на этих территориях.

Доказано, что население Луганской и Донецкой областей фактически оказалось в информационном вакууме, за каждым постом, твитом или статьей следят «органы государственной власти ЛДНР». В пунктах продажи прессы отсутствуют украинские газеты и журналы, в то время преобладают российские печатные СМИ.

Определено, что у местных жителей на неподконтрольных территориях искусственно формируют чувство страха к политике Украинского государства. В местной прессе прежде всего публикуются статьи о «шпионах» и «агентах» СБУ, а также создается ностальгия по Советскому Союзу, путем героизации безвести пропавших солдат «Великой Отечественной войны».

Ключевые слова: Украина, Россия, «гибридная война», «русский мир», неподконтрольные территории, масс-медиа, пресса, СМИ, ЛДНР, ЛНР (Луганская Народная Республика), ДНР (Донецкая народная республика). 